\title{
Phenology and phytomass of Crotalaria incana L. in the Eastern Amazon, Brazil
}

\author{
Renata Thaysa da Silva Santos ${ }^{1 *}$, Mailson Freire de Oliveira ${ }^{1}$, Vandeilson Belfort Moura ${ }^{2}$, Yanna Karoline \\ Santos da Costa ${ }^{1}$ and Rafael Gomes Viana ${ }^{2}$
}

\begin{abstract}
${ }^{1}$ São Paulo State University, Jaboticabal, SP, Brazil. ${ }^{2}$ Federal Rural University of Amazon, Belém, PA, Brazil.

*Author for correspondence: renata.thaysa@unesp.br
\end{abstract}

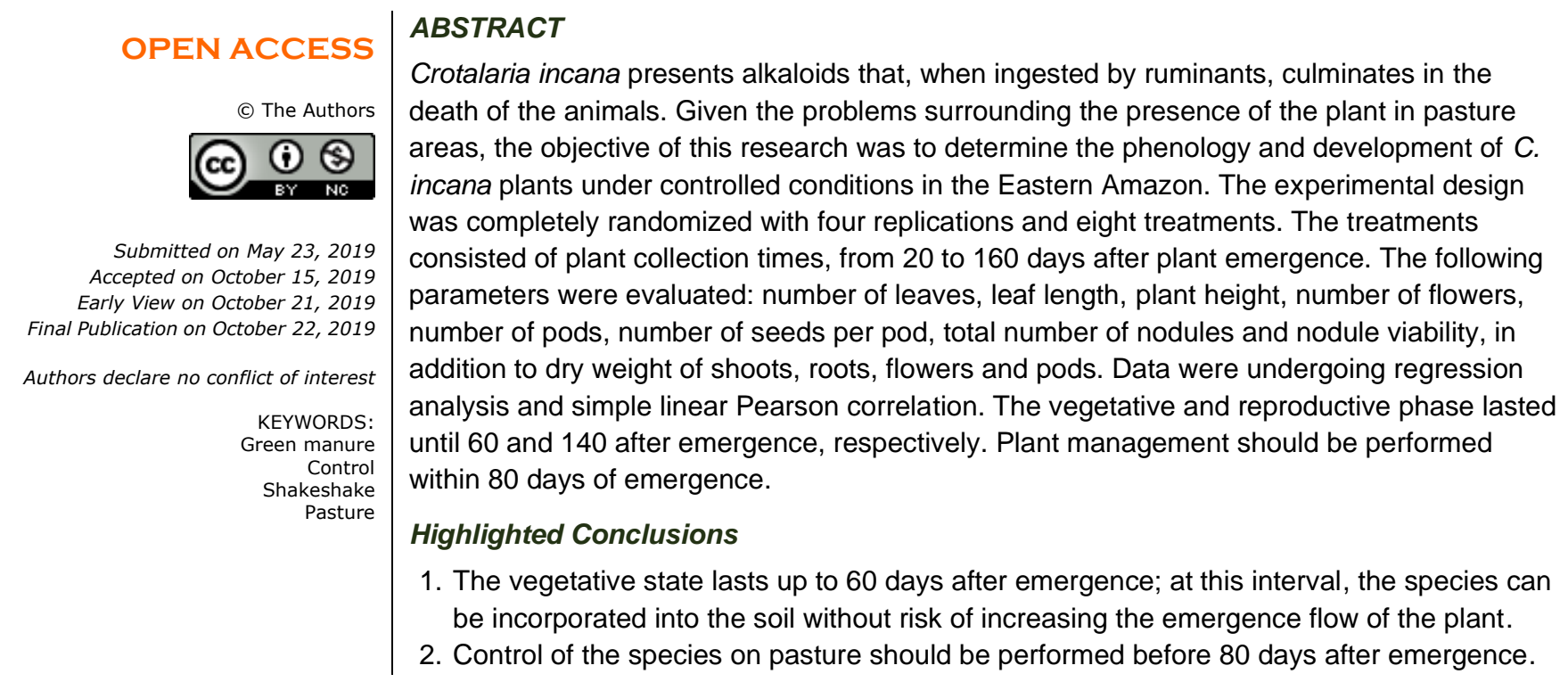

\section{INTRODUCTION}

In conservation crops, the use of legumes in green manure has produced important results for increase in productivity. The genus Crotalaria has shown significant participation in organic fertilization, contributing to management and recovery of degraded areas (Longo et al. 2011, Barretto et al. 2013). The characteristics of Crotalaria spp. include: significant benefits to chemical, physical and biological soil attributes, resulting from biological fixation of atmospheric nitrogen (N2) through symbiosis with Rhizobium genus bacteria; increased organic matter and nutrient recycling; high production of biomass and allelopathic substances that fight against fungi and nematodes; and a pivoting root that decompresses and allows further exploration of the soil (Amabile et al. 2000, Cunha et al. 2011).

The species Crotalaria incana L., popularly known as shakeshake, rattle, tick, or angry sesame, occurs in the tropics of Africa, Asia and America, and it belongs to the family Fabaceae-Faboideae (Leguminosae) (Flores and Miotto 2005). It has an annual cycle, and it is sub-bushy, branched, erect, with trifoliate composite leaves, alternating with glabrous ventral leaflets and dorsal pubescent leaflets, spreading through the seminiferous pathway (Lorenzi 2014). Described in the literature as a weed, $C$. incana produces pyrrolizidine alkaloids causing hepatic encephalopathy characterized by blindness, depression and aggression, progressing to cattle death within 48 hours after ingested (Queiroz et al. 2013).

The study of plant growth is aimed at evaluating the botanical characteristics of plant species in their developmental stages, from emergence to reproduction. Thus, Machado et al. (2006) consider it to be a reference tool that provides information, without the need for sophisticated equipment, to assist the choice of species of agricultural interest or even for weed control purposes.

Knowledge of $C$. incana is important, since there is little information in the literature about its phenology and development in tropical conditions, especially because these factors are influenced by photoperiod and air 
temperature. This information is crucial for proper management, because of the relevance of the species in agricultural areas.

Although $C$. incana is not yet used as a green manure by farmers, as occurs with Crotalaria juncea L. and Crotalaria spectabilis Roth, it is a potential legume for this soil management practice, provided that it is properly cut before the beginning of flowering to avoid the spread of seeds. Thus, the objective was to determine the phenology and development of $C$. incana plants under controlled conditions in the Eastern Amazon, Brazil.

\section{MATERIAL AND METHODS}

The experiment was carried out in a greenhouse of the Federal Rural University of Amazonia, Parauapebas, State of Pará, from March to August 2013, located in the following geographical coordinates: latitude $06^{\circ} 04^{\prime} 03^{\prime \prime}$ South and longitude $49^{\circ} 54^{\prime} 08^{\prime \prime}$ West, and average altitude of $150 \mathrm{~m}$.

Analysis of environmental conditions used data from the National Institute of Meteorology - INMET; particularly, data on the meteorological variables, provided by the conventional station, with observations made since 2008. The climate classification (Köppen 1918) of the municipality is type "Am": tropical, hot and humid; Parauapebas has average annual air temperature of $24.2 \stackrel{\circ}{\circ}$, relative humidity of $76.62 \%$, wind speed of $2.9 \mathrm{~m} / \mathrm{s}$, and precipitation of 1,201.84 mm (Figure 1).

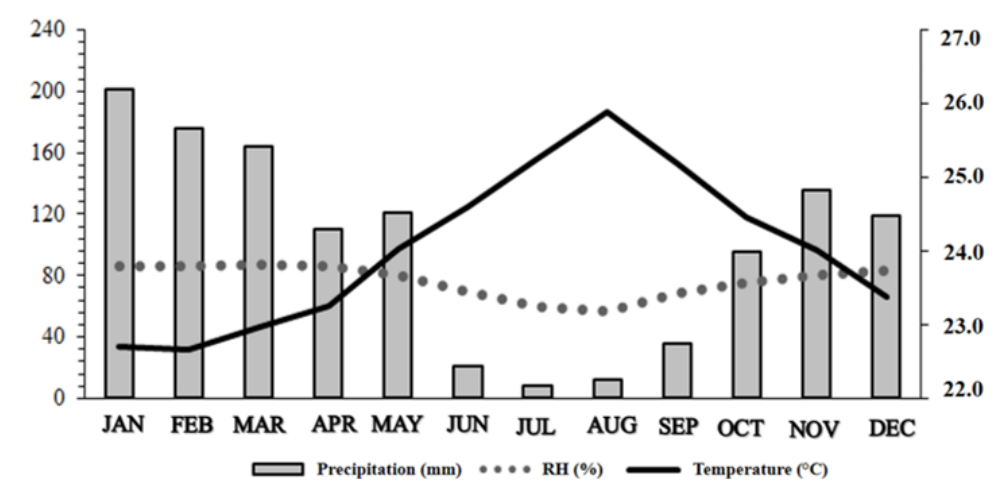

Figure 1. Climatic conditions of the municipality of Parauapebas, Pará, Brazil, for the variables Precipitation, Relative Humidity and Air Temperature from 2008 to 2016. Source: INMET.

Soil samples were collected in the superficial layer $(0-20 \mathrm{~cm}$ deep) from a pasture area and classified as a dystrophic yellow latosol (Embrapa 2013). The results of the chemical analysis of the soil (Table 1) followed the methodology used by Embrapa (1997); it was performed before the beginning of the experiment. The soil was always kept at field capacity; it was irrigated in the morning and in the late afternoon until the plastic pots had been drained, with a volume of $5 \mathrm{~L}$ capacity.

Table 1. Chemical attributes of a dystrophic yellow latosol from a pasture area before implementation of the experiment and slag application in Parauapebas, PA, Brazil, in 2013.

\begin{tabular}{|c|c|c|c|c|c|c|c|c|c|c|c|}
\hline Deep & O.M..$^{(1)}$ & & & $\mathbf{K}$ & $\mathrm{Ca}^{+2}$ & $\mathbf{M g}^{+2}$ & $\mathbf{A l}^{+3}$ & $\mathrm{H}+\mathrm{Al}$ & SB $^{(3)}$ & $\mathbf{V}^{(4)}$ & $m^{(5)}$ \\
\hline$(\mathrm{cm})$ & $\left(\mathrm{g} \mathrm{kg}^{-1}\right)$ & (water) & $\left(\mathrm{mg} \mathrm{dm}{ }^{-3}\right)$ & \multicolumn{6}{|c|}{ - $\left(\mathrm{cmol}_{\mathrm{c}} \mathrm{dm}^{-3}\right)^{-}$} & \multicolumn{2}{|c|}{$---(\%)$--- } \\
\hline $0-20$ & 19.39 & 5.63 & 0.64 & 0.17 & 1.29 & 0.75 & 0.10 & 3.06 & 2.21 & 41.9 & 4.34 \\
\hline
\end{tabular}

Crotalaria incana seeds were collected in February 2013 in urban and rural areas of Parauapebas and stored in paper bags, and then kept under controlled conditions of humidity and temperature until there was a sufficient amount of seeds to start the experiment.

The seeds were sown manually, and three pits were opened in each plastic pot; two seeds were sown per pit at a depth of $2 \mathrm{~cm}$. Ten days after seedling emergence, thinning was performed, and only three plants were left in each pot.

The experimental design was completely randomized with four replications and eight treatments, in a total of 32 pots. The treatments consisted of plant collection times, performed at regular intervals of twenty days, from 20 to 160 days after plant emergence (DAE). 
Every twenty days, the plants were collected and the following phytomass parameters were evaluated: number of leaves, leaflet length and plant height. The leaves were counted one by one, while considering the three leaflets as one leaf; leaflet length was measured by a graduated ruler $(\mathrm{cm}$ and $\mathrm{mm})$; the starting point was the insertion of the petiole to the tip of the simple limbus.

Plant height was also measured with the aid of a $50 \mathrm{~cm}$ graduated ruler, considering the neck of the plant as the starting point, approximately $1 \mathrm{~cm}$ from the substrate to the apical meristem of the plant (Figure 2).

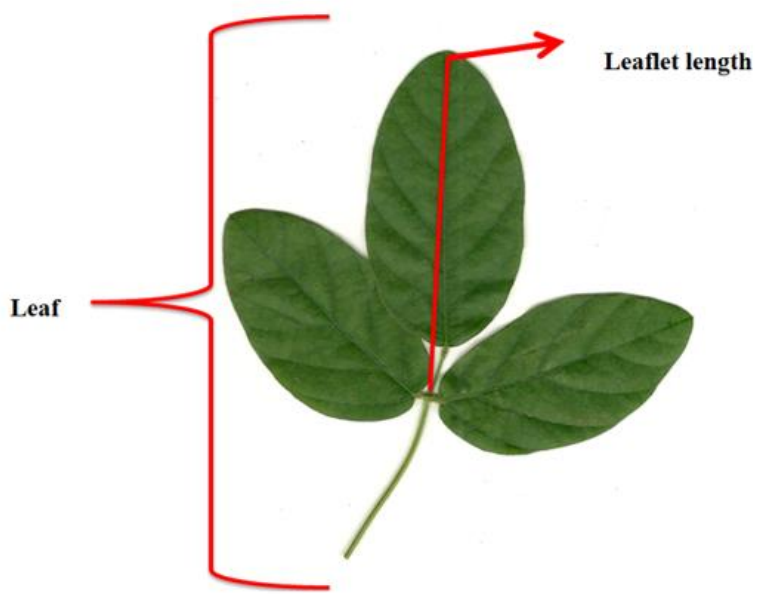

Figure 2. Representation of the measurement performed on Crotalaria incana L. plant at $\mathbf{4 0}$ days after emergence.

At the beginning of the reproductive phase, the following phytomass parameters were analyzed: number of flowers, number of pods and number of seeds per pod, total number of nodules and nodule viability. In addition to the evaluation of shoot and root dry weight in the vegetative phase during the treatments, dry weight of flowers and pods was also evaluated.

For determination of dry mass, the collected material was placed in a paper bag, identified, weighed on a precision scale and placed in a forced air circulation oven $\left(65 \pm 3^{\circ} \mathrm{C}\right)$ for 72 hours or to constant weight.

The mean values of the variables obtained and evaluated at the time of collection, such as number of leaves, plant height and leaflet length, underwent regression analysis, using the coefficient of determination. For the other variables, simple linear Pearson correlation analysis was performed (Barbosa and Maldonado Junior 2013).

\section{RESULTS AND DISCUSSION}

The seedlings of $C$. incana emerged 10 days after sowing because, at the beginning, germination and emergence are dependent only on the energy reserves contained in the seeds, and growth was slow at the beginning of the assessment of phytomass parameters, at $20 \mathrm{DAE}$.

Initial seedling growth from 20 to 40 DAE (Figure 3) remained constant in this experiment, and this phase, in previous studies with crotalaria, was little influenced by biotic factors, with no significant negative effect at different salinity levels in irrigation water on growth components of $C$. juncea and $C$. spectabilis seedlings (Santos et al. 2014).

After root development and leaf emergence, the plant showed linear growth up to $100 \mathrm{DAE}$, as a result of removal of water and nutrients from the soil by its roots, and of photosynthetic activity, owing to an increase in the number of leaves during the evaluation days; the highest number of leaves was found at 160 DAE (Figure 4).

In his work, Lorenzi (1991) describes that the target pubescent stem of $C$. incana is about 50 to $120 \mathrm{~cm}$ in height, which is similar to the height found in this study. The regression model that best adjusted the results found for the plant height variable was the cubic polynomial, with a maximum equation of $99 \mathrm{~cm}$ in length and a coefficient of determination of 0.97 . This indicates a high correlation of environmental conditions for development of the plant, which grows fats, with a maximum average height of $103 \mathrm{~cm}$ at $120 \mathrm{DAE}$.

Continuous growth also indicates that there was no decrease in the breathable surface, and the leaves were photosynthetic organs that did not suffer any biotic or abiotic interference; they had a good performance in the production of photoassimilates that contributed to plant development, as indicated in the phytomass parameter. There was no significant difference between the repetitions over the harvest seasons (Table 2).

The number of $C$. incana leaves indicates that this species has good soil cover and high dry weight production, which are essential for incorporation into the soil for nutrient cycling. The regression model that best fit the leaf 
number parameter was the cubic polynomial, which gave a coefficient of determination of 0.80 with a maximum equation of 80 leaves, with an average of 92 leaves between 120 and 160 DAE.

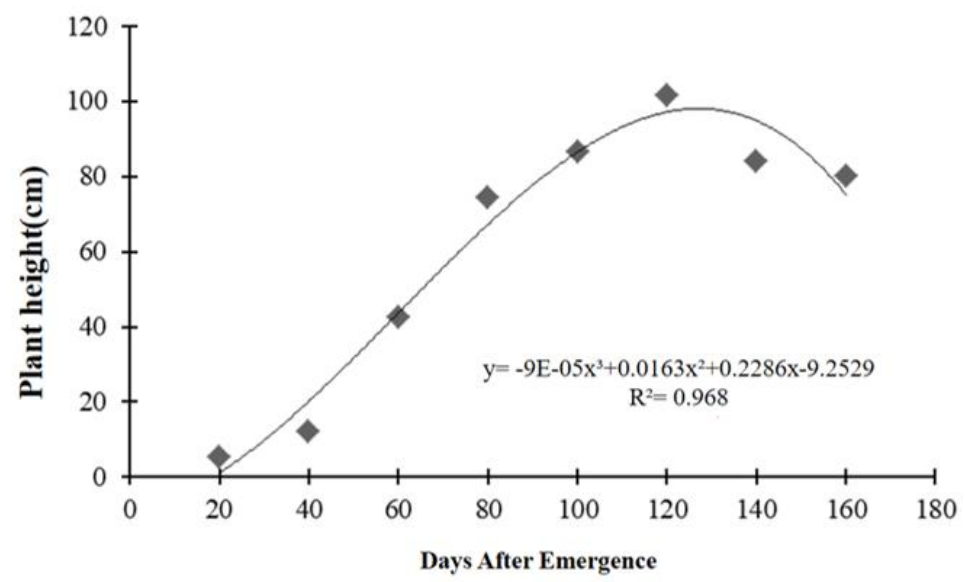

Figure 3. Plant height (cm) of Crotalaria incana L. kept in a greenhouse from 20 to 160 days after emergence in Parauapebas-

PA, Brazil, 2013.

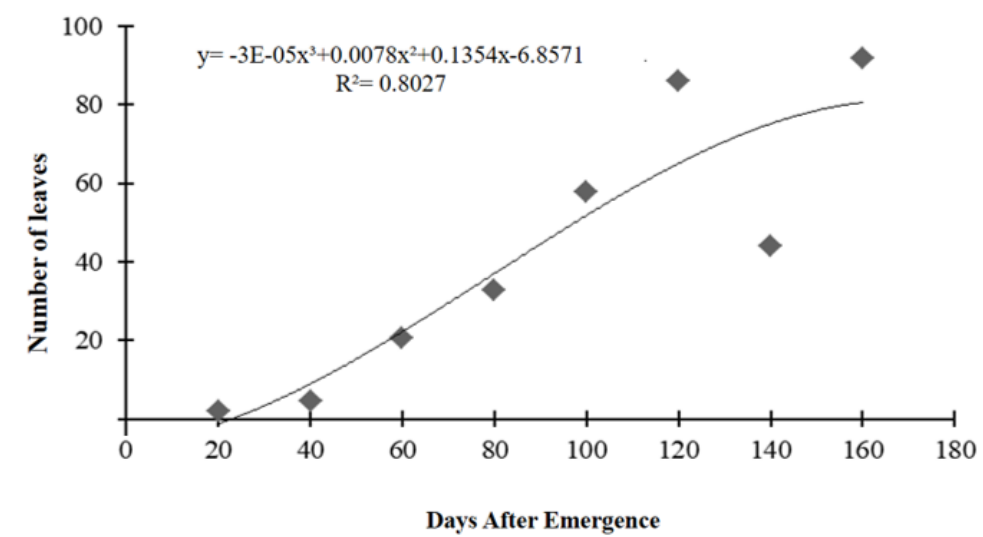

Figure 4. Number of leaves of Crotalaria incana L. from 20 to 160 days after emergence in a greenhouse in Parauapebas-PA, Brazil, in 2013.

Table 2. Pearson simple linear correlation coefficient between the variables time, viable nodules, unfeasible number of flowers and pods, shoot dry weight (SDW) and root dry weight (RDW).

\begin{tabular}{|c|c|c|c|c|c|c|c|}
\hline & Time & Viable nodules & Unviable nodules & Number of flowers & Number of pods & MS aerial part & MS Roots \\
\hline Viable nodules & $0,49229^{* *}$ & & & & & & \\
\hline Unviable nodules & $0,52697^{\star *}$ & $0,66839^{* *}$ & & & & & \\
\hline Number of flowers & $0,01029 \mathrm{NS}$ & $0,0577 \mathrm{NS}$ & $0,10868 \mathrm{NS}$ & & & & \\
\hline Number of pods & $0,08107 \mathrm{NS}$ & $0,01915 \mathrm{NS}$ & $0,05814 \mathrm{NS}$ & $0,400991^{*}$ & & & \\
\hline SDW & $0,64628^{* *}$ & $0,75176^{* *}$ & $0,80281^{* *}$ & $0,19001 \mathrm{NS}$ & $0,18368 \mathrm{NS}$ & & \\
\hline RDW & $0,70566^{* *}$ & $0,47378^{* *}$ & $0,64150^{* *}$ & $0,14311 \mathrm{NS}$ & $0,0094 \mathrm{NS}$ & $0,79825^{\star *}$ & \\
\hline Number of seeds per pod & $0,30364 \mathrm{NS}$ & $0,350183^{*}$ & $0,23164 \mathrm{NS}$ & $0,13087 \mathrm{NS}$ & $0,66843^{* *}$ & $0,29105 \mathrm{NS}$ & $0,9034 \mathrm{NS}$ \\
\hline
\end{tabular}

${ }^{* *}$ Significant at $1 \%$ probability of error by the T-test. * Significant at $5 \%$ probability of error by the T-test. NS: Non-significant by the T-test.

Timossi et al. (2011) found that crotalaria at 50 DAE had a suppressive effect on weeds, in line with the findings of Monquero et al. (2009) in Urochloa decumbens (Stapf) R.D.Webster (syn. Brachiaria decumbens Stapf.) and Panicum maximum Jacq. and Erasmo et al. (2004) in Digitaria horizontalis Willd. Hyptis lophanta Mart. ex Benth. and Amaranthus spinosus L., because of their rapid growth. They also found that, at $100 \mathrm{DAE}$, dry weight accumulation $\left(\mathrm{kg} \mathrm{ha}^{-1}\right)$ of weed plants was inhibited.

Crotalaria incana leaflets were longer at $60 \mathrm{DAE}$ than at the end of the vegetative stage. It was found that, after $80 \mathrm{DAE}$, there was a decrease in leaflet size (Figure 5) despite the increase in the number of leaves (Figure 4). Therefore, the vegetative phase lasted for $60 \mathrm{DAE}$, and the reproductive phase stated at $80 \mathrm{DAE}$ and 
lasted until 140 DAE. The reduction in plant size causes the metabolites to be directed to the reproductive structures.

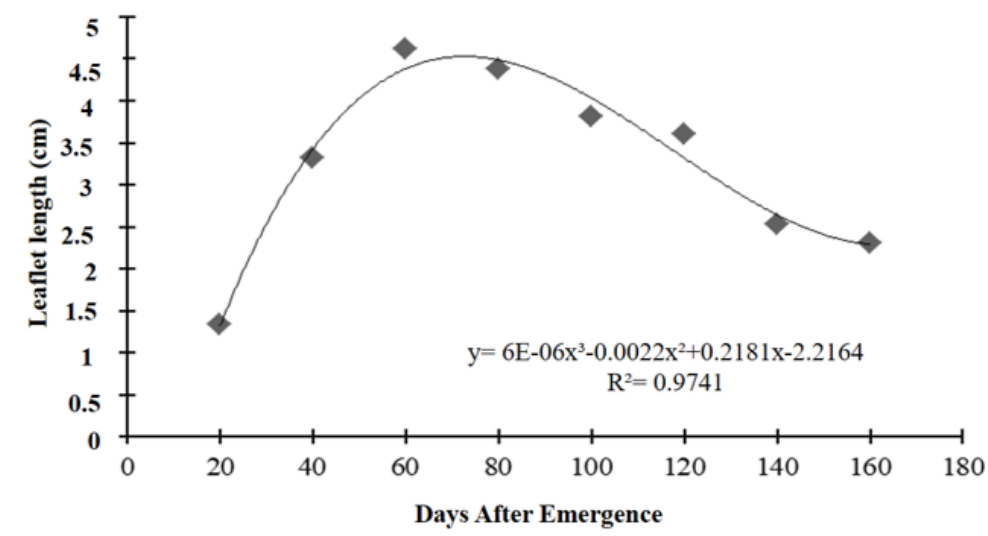

Figure 5. Length of Crotalaria incana L. leaflets kept in a greenhouse until 160 days after emergence in Parauapebas-PA, Brazil, in 2013.

The reproductive phase of $C$. incana started at $80 \mathrm{DAE}$, which shows a preference for a new distribution of photoassimilates in order for plants to produce axillary inflorescences in racemes of light yellow flowers, measuring 10 to $20 \mathrm{~cm}$ in length, and for formation of the fruit of the legume: an oblong, inflated, tomentous-pubescent pod 35-40 $\mathrm{mm}$ long that will act as a drain (Lorenzi 1991).

The duration of the vegetative phase of $C$. incana of only 2 months is a desirable technical characteristic, given the short time between harvest and sowing of the next crop in a no-tillage system, because time constraints pose a great challenge in the practical adoption of green manure in large agricultural crops in Brazil. Therefore, management should be carried out between 60 and $80 \mathrm{DAE}$, a result that corroborates the findings of Calegari (1995), who recommends cutting crotalaria after approximately 60 days of cultivation, but does not recommend cutting it when flower buds appear.

Because of its origin, Crotalaria demands heat, light and humidity, i.e., climatic conditions that are present in the Amazon region and favor its development. The experiment was conducted in autumn-winter 2013. Although the initial growth of $C$. incana it occurred in a period of lower solar radiation, the latitudinal position near the equator line makes insolation in the Amazon virtually constant throughout the year, with average annual global radiation of $650.40 \mathrm{~W} / \mathrm{m}^{2}$, and maximum and minimum temperatures of $33.2^{\circ} \mathrm{C}$ of $16.8^{\circ} \mathrm{C}$, respectively (Figure 6 ).

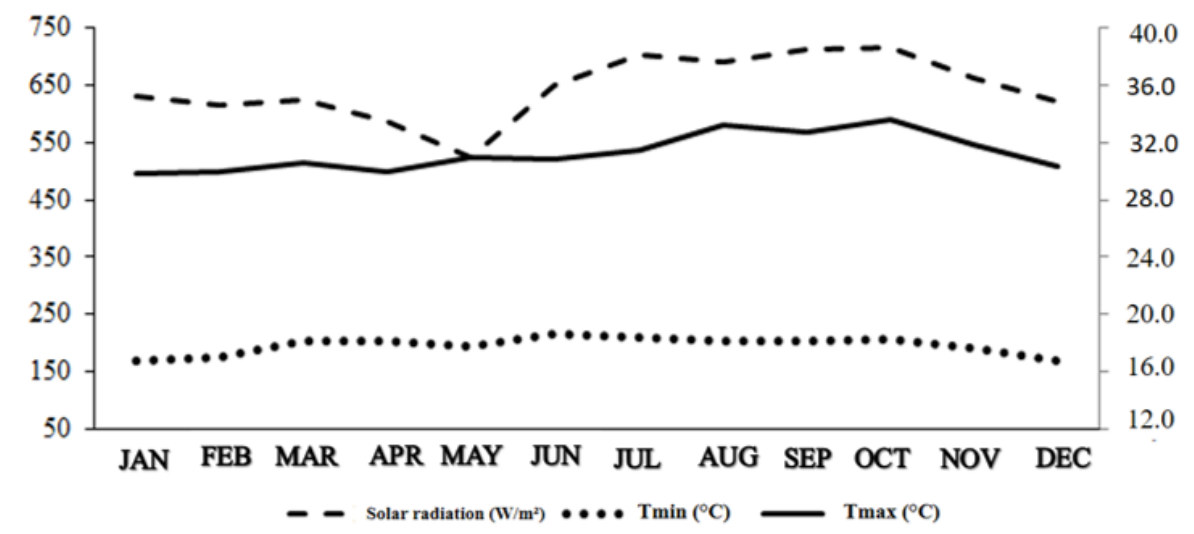

Figure 6. Global solar radiation incident on the municipality of Parauapebas, Pará, Brazilo, and maximum and minimum air temperatures from 2008 to 2016. Source: INMET.

Pereira et al. (2012), when evaluating the phytomass of several legumes, concluded that crotalaria presented the highest values of fresh matter, flowering at $68 \mathrm{DAE}$; thus, it was indicated as the best adapted green manure in the autumn-winter growing season.

The study of Cook et al. (1998) showed that the most favorable planting dates for genus plants vary according to the environment; plant height is affected by sowing time, with flowering of most cultivars occurring on short days 
and higher growth of crops conducted in the field occurring in spring, summer and early fall (Valenzuela and Smith 2002).

Leal et al. (2012) found the lowest growth values in early autumn sowing. However, in their study with crotalaria, they reported that there was no interaction between the effects of sowing season and cutting age on the relationship between the amount of dry matter and the aerial part.

The process of nodule development, which is the infection of the roots of the plant by Rhizobium bacteria that penetrate the root tissue, creating a strand of infection that grows to the cells of the root cortex that give rise to the nodules (Taiz and Zeiger 2017). It has a significant effect on the plant shoot growth and the root system of $C$. incana, as indicated by the significant correlations between these parameters (Table 2).

Symbiosis providing translocation of nitrogenous compounds results in significant phosphate triose production, which will result in growth and biomass accumulation of about 50 to $60 \mathrm{mg} \mathrm{ha}^{-1}$ green mass and 6 to $17 \mathrm{mg} \mathrm{ha}^{-1} \mathrm{dry}$ weight per species cycle; in addition, it provides plants in the reproductive phase with the capacity to produce and fill the pods (Perin et al. 2004, Vargas et al. 2011).

The non-viability of nodulation throughout the plant cycle, which started shortly after the reproductive period, is indicative that this mechanism present in the plant is an adaptation strategy that guarantees biomass accumulation. Such accumulation will contribute to improving the physical, chemical and biological attributes of the soil during growth and development of subsequent crops, with effective $\mathrm{N}$ supply of 170 to $300 \mathrm{~kg} \mathrm{ha}^{-1}$ (Santos and Fontanétti 2007, Vargas et al. 2011).

The increase in the number of unviable nodules, observed after the plant reached its final size at $120 \mathrm{DAE}$, indicates that $C$. incana started the senescence process at $140 \mathrm{DAE}$, with a decrease in dry matter accumulation because of the decrease in height and continued reduction in leaflet size until evaluations were completed at 160 DAE.

During the experiment, there was no need to apply herbicides, fungicides or insecticides; all the plants remained in adequate phytosanitary and edaphoclimatic conditions. Timossi et al. (2011), when conducting their research, identified infestation by powdery mildew (Erysiphe cichoraceum) in the leaves of crotalaria, which started at pre-flowering, with oviposition of Utetheisa ornatrix moth on the pods of plants, whose caterpillars, after hatching eggs, feed on the developing seeds, thus destroying them.

The vegetative state of $C$. incana lasted up to 60 days after emergence. Management should be carried out before the flowering period, either for soil incorporation or weed control purposes. Flowering starts at 80 days after emergence and lasts for 60 days throughout the reproductive cycle. Senescence begins at 160 days after emergence.

\section{Acknowledgements}

The authors are thankful to the Federal Rural University of Amazonia and the National Council for Scientific and Technological Development (CNPq) for the scientific initiation scholarship to the first author.

\section{References}

Amabile RF et al. 2000. Comportamento de espécies de adubos verdes em diferentes épocas de semeadura e espaçamentos na região dos cerrados. Pesquisa Agropecuária Brasileira 1:47-54.

Barbosa JC, Maldonado Júnior W. 2013. AgroEstat - Sistema para análises estatísticas de ensaios agronômicos. Versão 1.1.0.668. Jaboticabal: [s.n.].

Barretto VCM. et al. 2013. Adubação verde e nitrogenada na produtividade de milho e competição de plantas daninhas. Revista de Ciências Agroambientais 2:177-184.

Calegari A. 1995. Leguminosas para adubação verde no Paraná. Curitiba, IAPAR.

Cook CG et al. 1998. Planting date and cultivar effects on growth and stalk yield of sunn hemp. Industrial Crops and Products 8:89-95.

Cunha E Q. 2011. Sistemas de preparo do solo e culturas de cobertura na produção orgânica de feijão e milho: Parte II - Atributos biológicos do solo. Revista Brasileira de Ciência do Solo 35:603-611.

Embrapa - Empresa Brasileira de Pesquisa Agropecuária. 1997. Manual de métodos de análises de solo. 2.ed. Embrapa: Brasília.

Embrapa - Empresa Brasileira de Pesquisa Agropecuária. 2013. Sistema Brasileiro de Classificação de Solos. 3ed. Centro Nacional de Pesquisa de Solos Embrapa: Brasília.

Erasmo EAL et al. 2004. Potencial de espécies utilizadas como adubo verde no manejo integrado de plantas daninhas. Planta Daninha 3:337342.

Flores AS, Miotto STS. 2005. Aspectos fitogeográficos das espécies de Crotalaria L. (Leguminosae, Faboideae) na Região Sul do Brasil. Acta botânica brasileira 2:245-249.

Köppen W. 1918. Klassifikation der Klimate nach Temperatur, Niederschlag und Jahreslauf. Petermanns Mitt 64:193-203.

Leal MAA et al. 2012. Desempenho de crotalária cultivada em diferentes épocas de semeadura e de corte. Revista Ceres 59:386-391.

Longo RM et al. 2011. Recuperação de solos degradados na exploração mineral de cassiterita: biomassa microbiana e atividade da desidrogenase. Bragantia 70:132-138.

Lorenzi H. 1991. Plantas daninhas do Brasil: terrestres, aquáticas, parasitas, tóxicas e medicinais. 2.ed. Nova Odessa: Plantarum.

Lorenzi H. 2014. Manual de identificação e controle de plantas daninhas: plantio direto e convencional. 6.ed. Nova Odessa: Plantarum 
Machado AFL. et al. 2006.Crescimento de Digitaria insularis. Planta Daninha 4:641-647.

Monquero PA. et al. 2009. Efeito de adubos verdes na supressão de espécies de plantas daninhas. Planta Daninha 27:85-95.

Pereira GAM et al. 2012. Fitomassa de adubos verdes e cobertura do solo na região do Alto Vale do Jequitinhonha, Minas Gerais. Revista Agro@ mbiente On-line 6:110-116.

Perin A et al. 2004. Produção de fitomassa, acúmulo de nutrientes e fixação biológica de nitrogênio por adubos verdes em cultivo isolado e consorciado. Pesquisa Agropecuária Brasileira, Brasília 39:35-40.

Queiroz GR. et al. 2013. Intoxicação espontânea por Crotalaria incana em bovinos no norte do estado do Paraná. Semina: Ciências Agrárias 34:823-832.

Santos RA et al. 2014. Crescimento de leguminosas utilizadas na adubação verde em diferentes níveis de sais na água de irrigação. Revista Brasileira de Engenharia Agrícola e Ambiental 12:1255-1261.

Santos IC, Fontanétti A. 2007. Feijão-de-porco. In: Paula Júnior TJ, Venzon M. 101 Culturas - Manual de Tecnologias Agrícolas. Belo Horizonte: EPAMIG. pp.349-351.

Taiz L, Zeiger E. 2017. Plant physiology. 6.ed. Artmed: Porto Alegre.

Timossi PC. 2011. Supressão de plantas daninhas e produção de sementes de crotalária, em função de métodos de semeadura. Pesquisa Agropecuária Tropical 41:525-530.

Valenzuela H, Smith J. 2002. 'Tropic sun' sunnhemp. Hawaii: Cooperative Extension Service, College of Tropical Agriculture and Human Resources. 3p (Sustainable Agriculture Green Manure Crops SA-GM-11).

Vargas T O. et al. 2011. Influência da biomassa de leguminosas sobre a produção de repolho em dois cultivos consecutivos. Horticultura Brasileira 29:562-568. 